\title{
THE INFLUENCE OF HUMAN RIGHTS INSTRUMENTS ON CHILDREN'S RIGHTS JURISPRUDENCE: AN APPRAISAL OF THE ETHIOPIAN FEDERAL CASSATION COURT
}

\begin{abstract}
By
SOLOMON TEKLE ABEGAZ*

Department of Public Law, Faculty of Law, University of Pretoria, South Africa.

ABSTRACT

This article seeks to present the work of the Ethiopian Federal Cassation Court in fostering the application of the Convention on the Rights of the Child, the African Charter on the Rights and Welfare of Children, and the Constitution of the Federal Democratic Republic of Ethiopia. It discovers that children's rights jurisprudence is gradually evolving through the utilization of these legal instruments. This development challenges the current academic debate over the silence of Ethiopian courts with respect to their duty to invoke human rights provisions. Equally, it clarifies the confusion about whether Ethiopian courts exercise their mandate to interpret and apply human rights treaties. Nonetheless, the Court's involvement in areas including ensuring compliance with the vertical obligation of children's socio-economic rights is limited. The article then identifies the challenges that limit exercise of the Court's mandate, and suggests potential ways to enhance the Court's constitutional duty of protecting and promoting children's rights in the country.
\end{abstract}

\section{INTRODUCTION}

Children's rights would be meaningless if legal systems were unable to play an active role in their protection. Courts in both low- and middle-income countries play an increasingly important role in enforcing children's rights spanning civil and political, to economic, social, and cultural rights. ${ }^{1}$ In this way, they hold governments and other actors to account for their obligations to children's rights stipulated under the various law regimes. 
This article aims to interrogate the extent to and the manner in which the jurisprudence of the Ethiopian Federal Cassation Court (EFCC) has been influenced by the Convention on the Rights of the Child $(\mathrm{CRC}),{ }^{2}$ the African Charter on the Rights and Welfare of Children (ACRWC), ${ }^{3}$ and the Bills of Rights provisions stipulated under the Ethiopian Federal Constitution, ${ }^{4}$ and assess the position of the Court in responding to children's rights stipulated in these instruments, with a focus on the principle/right of best interests of the child, children's right to life, and their right to be heard. It records that a focus on children's rights and fledging child rights jurisprudence is gradually beginning to emerge in Ethiopia invoking these human rights norms. Although much is still to be done to reach the desired level, the sensitization and training that were given to the judiciary and the academic struggle over the years might have contributed to enhance the courts' capacity to deploy these instruments in their judgments. To a certain extent, this development challenges the current view over silence of Ethiopian courts with respect to their duty to invoke human rights provisions of the federal/state constitution. ${ }^{5}$ It equally clarifies the confusion over the application of human rights treaties ratified by Ethiopia before Ethiopian courts. However, it discerns that the EFCC's involvement is limited to only a few cases, considering the extent of violation of children's rights in the country. The article identifies the factors causing the limited role of the Court's engagement in children's rights and charts the way forward to enhance its role as an alternative path for vindicating children's rights.

The article begins with a brief introduction of children's rights under the CRC and the ACRWC. It is followed by a discussion on the role of courts in the realisation of children's rights, including children's socio-economic rights. ${ }^{6}$ It then moves on to examine the legal protection of children's rights in Ethiopia and the various 
judgments in which the Court makes reference to the applicable laws including children's rights instruments that the country has accessed. It also evaluates what the Court has achieved in this exercise, and identifies the areas in which its mandate is limited and the potential factors that militate against the Court's involvement. The article concludes by offering a way forward.

The article relies on human rights instruments and court cases to articulate the issues. EFCC decisions rendered between July 2005/2006 and July 2014 (the given period) are used for analysis. Children's cases mainly fall under the classification of family matters. I have thus examined this part to explore how and the extent to which the EFCC has deployed children's rights instruments

\section{II.. CHILDREN'S RIGHTS AND COURTS}

\section{Legal framework of children's rights}

A certain level of protection of children's rights through non-binding international instruments existed close to a hundred years ago. ${ }^{7}$ However, human rights were considered relevant only to the adult world, and the understanding that children are rights-bearers is a relatively recent development (Viljoen 2009: 353). In the pre-CRC era especially, children's issues did not fall within the scope of human rights (Cantwell 2011: 38). The idea that human rights only accrue to adults declined following the adoption of the CRC, which has been ratified by 195 countries - the most ratified treaty in history. Consequently, children's rights form part of the comprehensive system of human rights protection.

Because children are in the developmental phase of their lives, the CRC underlines that they need special protection as a vulnerable group. This position is the result of 
the international community's affirmation to create a 'special normative visibility, and, to an extent, "priority" for children's interests and needs due to this vulnerability" (Rosa and Dutschke, 2006:6). The CRC thus recognizes children's autonomy as rights holders but also takes cognizance of their vulnerabilities and their need for protection. It also explicitly enjoins the state with a '... duty to make the provisions of the CRC widely known to both adults and children and to assist parents and others responsible for the child, to implement these rights and shall in the case of need provide material assistance and support programmes particularly with regard to nutrition, clothing and housing' (CRC, articles 27(3) \& 44).

Soon after the adoption of the CRC, some African advocates maintained that the Convention failed to address important socio-cultural and economic realities peculiar to Africa (Viljoen 2000: 214; Olowu 2002: 128). As a result, the Assembly of Heads of State and Government of the Organisation of African Unity (OAU) adopted the ACRWC in July 1990. However, the two children's rights instruments have very similar provisions and are intended to be complementary, providing for children's wellbeing. Several CRC and ACRWC articles are similarly worded in other human rights instruments, ${ }^{8}$ but all the treaties must be read together and are meant to complement one another. Needless to mention, all the other human rights instruments equally apply to children. These two child-rights instruments are, however, peculiar in the sense that they address all rights of children holistically: social, economic, cultural, civil, and political (van Bueren 1999: 55). Following Hammarberg, the substantive rights of the CRC have been analysed and described in terms of rights relating to 'provision', 'protection', and 'participation' (the three Ps) (Covell and Howe 2001: 23). 
The rights of provision refer the rights of the child to economic welfare, healthcare, and childcare. ${ }^{9}$ The ACRWC is almost identical with regard to the rights provision except that the ACRWC does not contain the right of children to an adequate standard of living for the child's development or the right of parents to social security necessary for maintaining the standard of living of the child. The rights of protection refer to children's rights to be protected from harmful acts or practices. For instance, children have the right to be protected from abuse and neglect (CRC, article 19), economic exploitation (CRC, article 23), and sexual exploitation (CRC, article 34). Finally, the rights of participation refer to the rights of children to express an opinion in matters affecting them and to have that opinion heard (CRC, article 12).

The framers of the $\mathrm{CRC}$ and the $\mathrm{ACRWC}$ recognized that the interpretation and application of the instruments is not an easy exercise, given the many articles and broad language employed by these documents. In order to assist with interpretation and application of all the other articles, these instruments contain four important and interlinked general principles, namely: (a) the child's best interests; (b) the right to be heard or child participation; (c) non-discrimination; and (d) maximum survival and development of the child. The first two interlinked principles - 'the child's best interests' and 'child participation' - are worth discussing in the light of the fact that the EFCC predominantly used these principles for the determination of children's cases before it, and to demonstrate in my subsequent discussion if the Court has effectively deployed them.

It must be mentioned that the child's best interests is not a principle that stands alone. The debate as to the concept it conveys seems to have received better clarification with the adoption of the CRC Committee General Comment 14. It has 
now spread to all other areas of the law as a guiding principle, a substantive right, and a rule of procedure in decisions to be made about children. ${ }^{10}$ In its function as a principle, the CRC refers to best interests as being 'a primary consideration' in matters concerning the child (CRC, article 3(1)). The Charter, on the other hand, goes one step further by stating that the best interests principle shall be the primary consideration (ACRWC, article 4). In some national laws such as Section 28(2) of the South African Constitution of 1996 refers to a child's best interests as being 'of paramount importance' in every matter concerning the child.

The best interests principle conveys that decision-makers have to seriously consider what would be in the best interests of the child, including in actions concerning their economic and social welfare. In addition, it implies that due to the special situation of the child (such as, incapacity, voicelessness and dependency), the child's best interests may not be considered on the same level as all other considerations. ${ }^{11}$ Whilst 'a primary consideration' leaves best interests competing equally with other rights on the same footing, 'the primary consideration' suggests that children's best interests must be given a heavier weighting where there are competing rights. There could be situations where children's interests run in conflict with others such as parents, the public or other children. In such scenarios, the 'primary consideration' phrase requires judicial and other organs to be explicitly aware of children's interests being given high priority, and not just one of several considerations. However, the best interests of the child will not always be the single overriding consideration. Skelton (2009: 487) notes in the various cases entertained by the Court, the SACC has clarified that the paramount principle is not an absolute trump over rights against others. ${ }^{12}$ According to this Court, in as much as such limitation is reasonable and justifiable a child's best interests right can be limited. 
For proper application of the child's best interests, human rights law imposes different layers of obligations of which one is the obligation to ensure that all judicial and administrative decisions as well as policies and legislation concerning children demonstrate that the child's best interests have been a primary consideration. Besides, in giving effect to the child's best interests, judicial and non-judicial organs of the state are under obligation to give equal attention to the universal, indivisible, interdependent and interrelated spectrum of children's rights. ${ }^{13}$ This implies that courts of law and quasi-judicial bodies should apply the principle, not only to children's rights but to parental or other care-takers' responsibilities in relation to children's proper upbringing or other issues affecting children, but also to state and all other non-state actors to protect all children's rights proclaimed in the CRC. Further, these institutions are under an obligation to ensure the best interests of the child are considered in all issues and decisions which have an important impact on the life and development of the child, whether of a procedural or substantive nature, and must demonstrate that they have effectively done so. ${ }^{14}$ To protect children's best interests before these and other institutions, States Parties are equally urged to make provisions for young children to be represented independently in all legal proceedings by someone who acts for the child's interests, and for children to be heard in all cases where they are capable of expressing their opinions or preferences. The latter duty of states towards children leads to the discussion on the second and interlinked principle of the child's right to be heard.

'The right to be heard' or 'child participation' is the second principle. The relevant provisions of the CRC and ACRWC require States Parties to 'assure to the child who is capable of forming his or her views the right to express those views freely in all 
matters affecting the child, the views of the child being given due weight in accordance with the age and maturity of the child' (CRC, article 12(1); ACRWC, article 7). ${ }^{15}$ The term 'participation' is not explicitly mentioned in both of these articles. However, the national and supra-national children's rights movement aimed at promoting the implementation of these articles has evolved in a wide use of the term to describe on-going processes, which include information-sharing and dialogue between children and others. ${ }^{16}$ As the child's or children's right to be heard is a crucial element of such on-going processes, these processes are understood as participation.

The right to be heard is a right of the individual child and a right of groups of children in all matters affecting him or them. States Parties must assure the right according to the age and maturity of both the individual child and children as a group. Not only have the above articles established that child participation is a right in itself, they also require attention be paid to give effect to them in the interpretation and implementation of all other rights. In order to implement them effectively, States Parties are required to provide an environment that enables the child to exercise her or his right to be heard in decision-making, policy-making and preparation of laws and/or measures as well as their evaluation. Besides, States Parties must either directly guarantee this right, or adopt or amend their laws to ensure enjoyment of the right by the child or children in decision-making processes. Relevant judicial proceedings which affect the child and require respecting the view of the child include: custody, care and adoption, separation of parents, children in conflict with the law, child victims of physical or psychological violence, sexual abuse or other crimes, health care, and social security. Whenever a decision is made in relation to 
these and other matters affecting the child, the view of the child must be taken into account in order to determine the best interests of the child.

The expressed commitment to advance the respect, promotion and protection of fundamental norms and principles of the child discussed in the above paragraphs raises questions about the specific role of the judiciary in the promotion of children's rights. The article now turns to a consideration of the role of courts in the development of jurisprudence for the realisation of children's rights. In this discussion, the article highlights the contribution of the South African Constitutional Court (SACC) as examples that could potentially be utilized to elicit good practice for judicial officers, practitioners and other law enforcement professionals in Ethiopia. The focus on the South African system is because it has been hailed internationally as good example in enforcing children's rights in a developing economic setting. (Alston and Tobin 2005: 7).

\section{The role of the courts}

The CRC has identified a wide range of measures that are needed for its effective implementation, of which the judiciary at all levels is one. ${ }^{17}$ Children's rights ranging from civil and political, to economic, social and cultural provided both in the CRC and ACRWC are justiciable rights or rights capable of being claimed through judicial

means. ${ }^{18}$ The justiciability of these rights bestows the obligation on courts to craft transformative remedies when a violation is established (Liebenberg 2010: 37). The courts must play a meaningful role in the realisation of a better life for disadvantaged children, particularly where states remain unaccountable for violations of children's rights. Judicial enforcement will support the implementation of rights-based claims, giving meaning to a country's longstanding obligations to children's rights. It is not 
possible to discuss all the cases and areas affecting children's rights. However, by focusing on the contribution of the SACC, I emphasize the significance of enforcing children's rights using the 'best interests' principle. It is on this basis that the work of the EFCC is measured.

Bonthuys (2006: 39) observes that this principle is used in different ways, in some instances by ignoring its existence as a constitutional principle and self-standing right, rather than a common-law principle. It is also worth mentioning what Sachs $\mathrm{J}$ noted in a similar matter: 'South African courts have long had experience in applying the "best interests" principle in matters such as custody or maintenance. In our new constitutional order, however, the scope of the best interests principle has been greatly enlarged'. ${ }^{19}$ In addition, the SACC has invoked the best interests in various case $^{20}$ with reference to article 3 of the CRC or article $3(b)$ of the South African Constitution. Skelton (2003: 6) also notes that 'due to the "expansive guarantee" provided by section $28(2)$, it is clear that this principle (i.e. the best interest principle) - which has also been interpreted by the Constitutional Court to be a self-standing right - is a central feature in litigation relating to children's right to education'. Skelton further notes that the SACC has drawn the best interests into cases pertaining to the right to family and parental care; international child abduction; child pornography; the right to housing or shelter; adoption of children by an unmarried father, by same sex couples and by foreign couples; inheritance under customary law; the right to access healthcare in the form of preventive anti-retroviral medicines; the right to social assistance; the right of children to privacy and dignity; the testimony of child witnesses and victims; the right of children not to be detained except as a measure of last resort; and the right to a basic education. ${ }^{21}$ 
The SACC's decisions demonstrate that the best interest principle is used equally to interpret children's socio-economic rights, underscoring the vertical obligation of state responsibility for children's rights. This exemplifies that courts have a significant role to play (using the best interests), not only to resolve family or child custody issues, but also to hold the executive accountable to fulfil children's rights (Guari and Brinks, 2008: 34). In what follows the article examines the jurisprudence of the EFCC relating to children's rights in Ethiopia in the given period. It then analyses how courts use the best interest and other rights of children to articulate and accommodate the rights and interests of their parents or care-givers.

\section{CHILDREN'S RIGHTS AND THE FDRE CASSATION COURT}

\section{Legal protection of children's rights in Ethiopia}

Since the beginning of the 1990s Ethiopia has come a long way in recognizing children's rights. The adoption of FDRE Constitution has a specific provision on children, ${ }^{22}$ and the ratification of the UN CRC ${ }^{23}$ and the $A C R W C^{24}$ are three very important achievements. These instruments impose a range of obligations for the promotion, protection and realisation of children's rights. However, there are still legislative measures aimed at protecting children's rights that Ethiopia must address. ${ }^{25}$

Following the ratification of the above instruments and the constitutionalizing of children's rights, the government has adopted a multi-sector child-friendly approach by establishing regional courts and setting up child protection units at most police stations (Alemu and Birmeta 2012: 129). In addition, hospitals have been strengthened to provide medical and counselling services for child victims in 
accordance with international principles and standards; and major stakeholders such as judges, police officers, social workers and health professionals have received training to coordinate their efforts to contribute to the prevention of child abuse.

Nonetheless, most of the promises contained in those treaties ratified by the country are yet to be given effect. Although the country has shown economic growth in the past decade, the reality of the socio-economic rights of children in Ethiopia remains disturbing (Goel 2009: 152). In the following sub-section, I highlight some of the problems faced by children in Ethiopia that have perhaps not been given adequate attention.

\section{Brief overview of realities of children's rights in Ethiopia}

Since 2004 Ethiopia has achieved poverty reduction through its development policies, strategies and programmes. ${ }^{26}$ However, Ethiopia still has a high rate of infant mortality with an estimated 88 deaths per 1,000 live births. ${ }^{27}$ These deaths are usually due to treatable illnesses such as pneumonia, malaria, roseola, and diarrhoea. While Ethiopia's GDP has risen steadily over the past decade, rates of malnutrition and starvation-related morbidity remain extremely high. In addition, harmful traditional practices that affect children such as female genital mutilation, milk teeth extraction, food taboo, uvula cutting, keeping babies out of exposure to the sun, and feeding fresh butter to new born babies continues to be practised in the rural parts of the country (Gebrekristos et al 2014: 1-7). Other forms of child abuse and neglect such as child labour prevail (Save the Children, Sweden, 2010).

In 1997, school attendance became mandatory for children aged seven to sixteen. However, the Committee on the CRC is concerned that education is still neither free 
nor compulsory and that net enrolment remains low. $^{28}$ It is also concerned with issues such as charging fees for primary education, overcrowding of schools, limited provisions for vocational training, low transition rates to secondary school, insufficient numbers of trained teachers and availability of school facilities, absence of budget allocations for pre-primary schools and poor quality of education. ${ }^{29}$

Despite progress made following targeted measures by government, an estimated 150,000 children continue to live in the streets (Humanium 2012) where they fall victim to drug addiction, sexual exploitation or are routinely harassed by the police. One other problem is the failure of parents, especially fathers (Ibid), to provide child maintenance. Lack of maintenance affects practically every right required for the survival and development of the child, such as the right to life, survival, physical, moral and intellectual development, and active participation in society, cultural life and protection from harmful influences.

The CRC Committee has noted: 'Childhood is a unique period of physical, mental, emotional and spiritual development and violations of children's rights ... may have life-long, irreversible and even trans-generational consequences'. ${ }^{30}$ Measured against this view, the present realities of our children are unacceptable and highlight the government's slowness in action to actualize children's rights. Children's rights to access to nutrition, health and education are the minimum rights that a country at any level of development must protect, respect and fulfil. When the elected branches of government become unresponsive to children in dire need of protection, the courts have increasingly played an active role for the realisation of their rights (Guari and Brinks, 2008: 34). Ethiopia has expressed a commitment to advance the respect, promotion and protection of the rights of children. Such a commitment raises 
questions about the specific role of the judiciary in the promotion of children's wellbeing. In sub-section III.3, I describe the EFCC jurisprudence in fostering the application of the CRC, ACRCW and domestic legislation for the enforcement of children's rights and evaluate what the Court has achieved or otherwise in its engagement of these cases.

\section{Jurisprudence of the EFCC}

The 1991 regime change in Ethiopia has profoundly transformed the country's judicial structure. A sharp increase in the number of courts at the lower levels of administration has provided citizens with better legal access, both physically and in allowing the use of local languages in the courts. Chapter 9 of the FDRE deals with the role, structure, and function of the Ethiopian judiciary. Pursuant to this Constitution, not only does the Federal Supreme Court have the highest and final judicial power over federal matters, it also has the power to review the judgments of the federal supreme court and those of the two self-administrative cities, which have the highest and final judicial offices in their respective jurisdictions (FDRE Constitution, article 80(1) \& (6)).

Furthermore, pursuant to Federal Courts Proclamation Re-amendment 'interpretation of a law by the Federal Supreme Court rendered by its cassation division with not less than five judges is binding on federal as well as regional courts'. ${ }^{31}$ Thus, the Cassation Division of the Federal Supreme Court can review a decision of any court in Ethiopia. This legislation also imposes a duty on the Court to 'publish and distribute decisions of the cassation division that contain binding interpretation of laws to all levels of courts and other relevant bodies' (Proclamation 454/2005, article 2(5)). The decisions of the EFCC thus have the force of law. At the time of writing, 
the Court has published 16 volumes of its decisions. In this article I examine the part relating to children's rights contained in the category for family matters, and a case included in the classification dealing with tort cases.

It is very important for the purpose of this study to: (a) chart how in recent years, courts of law in Ethiopia have been applying the best interests principle in adjudicating children's cases; (b) gauge the manner in which the EFCC has applied the principle, and; (c) analyse its implications for the development of children's rights jurisprudence in Ethiopia.

\section{A. Best interests}

In the study period, global and regional instruments and the FDRE Constitution were employed to support the best interests principle in the following EFCC judgments. In the first case, the judgment handed down by the EFCC in Ms Tsedale Demissie (applicant) $v$ Mr Kifle Demissie (respondent) ${ }^{32}$ referred for the first time to the relevant provisions of the $\mathrm{CRC}$ and the FDRE Constitution concerning the principle of the best interests of the child. The case involved a dispute over the custody of a child, which was initiated before a Woreda Court in the Bonga area of Kafa Zone of the Southern Nations, Nationalities and Peoples Regional State (SNNPRS) ${ }^{33}$ In the Woreda Court the respondent sought a declaration that he was guardian and tutor of his minor child, Binyam Kifle. The Court granted the request in accordance with article 235(1) of the Family Code of the SNNPRS. ${ }^{34}$ However, the applicant filed an opposition pursuant to article 358 of the Civil Procedure Code ${ }^{35}$ challenging the declaration as the respondent had failed to provide care, protection and assistance to the minor for 12 years. The applicant pleaded that she be appointed guardian and tutor of the child as she was the one who had been caring for the child. The Court, 
however, relying on the above article of the Family Code of the SNNPRS, rejected the applicant's submission, reasoning that an aunt is not entitled to guardianship and tutorship powers and duties while a minor's father still is alive. ${ }^{36}$

The applicant appealed the decision of the lower court in the High Court of Kafa Zone, restating the argument she raised in the lower court, claiming the respondent unworthy to be appointed guardian and tutor. However, the High Court reaffirmed the decision of the lower court and rejected her appeal on the same reasoning raised by the lower court. Nevertheless, dissatisfied with the decision of the High Court, the applicant appealed to the SNNPRS' Supreme Court for the reversal of the decision of both courts arguing that their decision was based on a fundamental error of law. To her dismay, the State Supreme Court reaffirmed the decision of the two lower courts.

In March 2006, the applicant finally appealed to the EFCC on the grounds that the decision of the two lower courts constituted a fundamental error of law. The obiter dictum given by this Court is critical for the purpose of this work - for the Court relied on the CRC and Bill of Rights provisions of the FDRE Constitution and special legislation for disposition of the case. In its decision, the Court invoked article 36(2) of the FDRE Constitution which provides: 'the best interests of the child shall be the primary consideration in deciding all matters concerning the child'. ${ }^{37}$ Equally important, the Court invoked article $3(1)$ of the CRC which stipulates that the best interests be 'a primary consideration' in matters concerning the child. In giving careful and deliberate consideration to the case, the Court also made a determination about the status of the CRC using article 9(4) of the FDRE Constitution. It underscored that the $\mathrm{CRC}$ is part and parcel of the domestic law of 
Ethiopia, on the basis of which the application of article $3(1)$ of the CRC shall be observed by the judiciary. It emphasized that the principle of the best interests of the child shall be given primary consideration irrespective of the domestic law's requirement of giving primacy to parents of children for the purpose of guardianship and tutorship. The Court criticized the lower courts' failure to consider the best interests of the child in view of the fact that the it was proved that the respondent had failed to visit, care, support or fulfil all other obligations that a prudent parent would have discharged towards his son. Accordingly, the Court reversed the decision of the lower courts and granted the power of guardianship and tutorship to the applicant.

In the second case in which the EFCC invoked the CRC, the ACRWC and the Bill of Rights provisions of the Constitution was Ms Etsegenet Eshetu (applicant) $\mathrm{v} M s$ Selamawit Nigussie (respondent). ${ }^{38}$ The case was initiated before the Federal First Instance Court (FFIC) of Addis Ababa City Government where the respondent sought the validation of the will made by the deceased, Mr Zenebe Nigussie. One of issues covered in the testament related to guardianship and tutorship of the child, Natnael Zenebe. In his will the deceased authorized the respondent to be guardian and tutor of the child, while the child's mother was alive. The FFIC accepted the plea of the respondent and accordingly validated the testament. Later on, the applicant filed a pleading to the same court opposing its decision in accordance with article 358 of the Civil Procedure Code of Ethiopia. Among other things, she opposed the validity of the will on the grounds that the deceased could not, in his will, deprive a mother from becoming the guardian and tutor of her child. Having reviewed the application, the Court accepted the applicant's plea and cancelled its previous decision. 
The respondent then appealed the decision to the Addis Ababa Appellate Court. However, the Appellate Court reaffirmed the decision of the lower court. The decision was then further appealed in the Cassation Division of Addis Ababa City Court which finally overturned the decision of the lower courts on various grounds, and accepted the validity of the testament. It was on the decision of this latter court that the case was appealed to the EFCC. In her petition to the EFCC, the applicant submitted that the decision of the Cassation Court of Addis Ababa constituted a fundamental error of law in reversing the decision of the lower courts. The EFCC determined that the matter needed further investigation, and thereafter delivered a final judgment in which it explicitly invoked the principles on the best interests of the child as stipulated under article 4(1) of the ACRWC; and articles 3(1) and 36(2) of the CRC. It also resorted to articles 9(4) and 13(2) of FDRE Constitution which enabled the Court to interpret the children's rights instrument on the case before it. In its obiter dictum the Court underlined the importance of these instruments in determining the custody and propriety concerns of the child. Finally, the Court decided that the testament, if interpreted according to the given circumstance of the child, would not be in the best interest of the child. Before the Court reached this conclusion it summoned the child who revealed that he was not receiving the necessary care and protection from the respondent. Accordingly, the Court found the decision of the Addis Ababa City Cassation Court constituted a fundamental error of law. It then ordered the applicant to take guardianship and tutorship of the minor.

The third case was Mr Francis Pastor (applicant) v Mr Duckman Vino \& Ms Barbot Letitiya (respondents). ${ }^{39}$ The case was first filed before the FFIC in Addis Ababa where a childcare institution run by the applicant pleaded for cancellation of an adoption agreement signed with the respondents. The alleged ground for 
cancellation was the respondents' change of mind not to adopt a child, contrary to their prior agreement. The childcare institution believed that the incident would endanger the child's future. However, the lower court dismissed the application, reasoning that the respondents' change of mind did not necessarily pose a risk to the child. The applicant then filed an appeal to the Federal High Court opposing the lower court's decision. The High Court, however, reaffirmed the lower court's decision.

The decision was finally appealed to the EFCC on the grounds that the decisions of the lower courts constituted a fundamental error of law. Similar to the first two cases discussed, the EFCC underlined the principle of the best interests of the child. However, this time the Court tried to look at the best interests of the child in the light of adoption. In its obiter dictum the Court clearly highlighted that the $\mathrm{CRC}$, the ACRWC, and Ethiopian legislation require the best interests of the child to be taken as a paramount consideration in relation to adoption. In addition, the Court underscored that the country is bound to apply these human rights instruments in accordance with article 9(4) of the FDRE Constitution. Using these instruments and the domestic legislation as a framework, the EFCC overturned the decision of the lower courts and declared the the adoption agreement invalid. The Court reasoned that it was not possible to reach a conclusion that no harm would occur to the child when seen in the light of the respondents' original expression of lack of interest to adopt the child, and where they had not shown their disagreement with the applicant's plea for cancellation of the agreement at the FFIC level. ${ }^{40}$

A fourth case was Bete Zata Children's Home Association \& others (3 applicants) $v$ None (Bete Zata Children's Home). ${ }^{41}$ In short, the case involved a request for the 
invalidation of a child adoption agreement on the grounds of the mental condition of the child, alleged to have been revealed after the agreement was executed. The FFIC, however, rejected the application. Similarly, the Federal High Court dismissed the claim in its appellate jurisdiction. The case was finally taken to the EFCC where the Court overturned the decision of the lower courts by accepting the plea of the applicants. It accordingly ordered the invalidation of the agreement and in so doing the Court embraced long-term considerations for the child in the light of the best interests principle.

On family matters, the four cases discussed are the ones in which the EFCC explicitly makes reference to global, regional, and Ethiopian domestic legislation in the context of the best interests of the child. Interestingly, the trend shows that other federal and regional courts of law, at different levels, in the country also increasingly apply the principle in the adjudication of family law cases (Alemu and Birmeta, 2012: 45).

\section{B. The right to be heard}

This right to be heard is well recognized under articles 12 and 4 of the CRC and the ACRWC, respectively. It is also stipulated under articles 249(2) and 291 of the Revised Family Code of Ethiopia. These instruments guarantee any child capable of forming his/her views the right to be heard in any judicial and administrative proceedings affecting them, either directly, or through a representative or an appropriate body, in a manner consistent with the procedural rules of national law.

Although it is not explicitly expressed in the European Convention on Human Rights, a recent positive development at the European Court of Human Rights is its 
increasing reference to the child's right to be heard under article 12 of the $\mathrm{CRC}{ }^{42}$ Coming to the jurisprudence of the EFCC concerning this right, the case of Etsegenet Eshetu ${ }^{43}$ discussed at III. 3.A. is relevant. While determining the best interests of the child in this case, the child's views were also respected in the Court's process. Part of the reasoning of the Court relates to the right of children to express their views freely in all matters affecting them. The Court explicitly recognized that respect for the views of the child is another principle which is given utmost importance in global and regional treaties on child rights in addition to the principle of the best interests of the child. In relation to this, the Court unequivocally invoked articles 12 and 4(1) of the CRC and the ACRWC, respectively and heard the views of the minor, who indicated that he wished to live with the appellant. It was on this basis that the Court decided the applicant be confirmed as guardian and tutor of the child.

The Court's approach is in agreement with the interpretation given by the Child Rights Committee under the $\mathrm{CRC}$ as to the interdependence or interlink between the best interests and participation principles elaborated under General Comments 14 and 12 , respectively. However, the fact that reference to the child's right to be heard was made only in the present case during the given period indicates that the Court has a long way to go to embrace this right fully.

\section{The right to life}

The right to life is a universally recognized human right affirmed in various international ${ }^{44}$ and regional ${ }^{45}$ human rights instruments and national constitutions. ${ }^{46}$ In the context of children, children's right to life includes their chance to be able to live and have the possibility to grow, to develop, and become adults. Included are 
the right to have one's life protected from birth and the right to be able to survive and develop appropriately (Humanium, n.d). This right protects children from subjection to killing, the death penalty, acts of infanticide, and protection from preventable death.

In one of its most recent decisions rendered in December 2013, and incorporated in the current compilation of this Court's decided cases (volume 15), the EFCC entertained a tort case involving the death of a 13-year-old child. The case was litigated between the Ethiopian House of Federation \& Mr Tesfahun Getahun v Priest Mamo Yitaferu. ${ }^{47}$ Tesfaye Getahun (second applicant) was a driver employed by the Ethiopian House of Federation (first applicant). On 16 May 2010, the first applicant gave a free ride (service for non-consideration) to the deceased child while the former was on duty in the vicinity of Addis Ababa. The child who was seated at the back of the vehicle fell off the vehicle and died. This incident gave rise to court action that finally reached the EFCC. At the FFIC, the respondent claimed a total amount of Birr 119,870 by way of compensation for allegedly wrongfully causing the death of his child. The first applicant was sued as the owner of the vehicle. The applicants, who were respondents in the FFIC's file, argued they were not responsible and liable to pay for the death. The FFICfound the applicants responsible for the death of the child and ordered them to pay Birr 31,300 to the respondent. Later, the applicant appealed against this decision in the Federal High Court in accordance with article 337 of the Civil Procedure Code of Ethiopia. ${ }^{48}$ However, the Appellate Court dismissed the appeal. It was from the decision of these two tier courts that the case was brought before the EFCC. ${ }^{49}$ 
The EFCC framed the main issue as being whether it was proper for the FFIC to hold the applicants responsible for the death of the child. The Court stated that the accident related to vulnerable groups that need special protection from society. It relied on the facts which were proved at the FFIC that the second applicant failed to take the necessary precautions to preserve the safety of the child while driving him. Most importantly, the Court reiterated that the death constituted deprivation of the right to life of the child stipulated under articles 36(2), 15, and 25 of the FDRE Constitution and explicitly mentioned that the death was in violation of the treaties ratified by Ethiopia, more specifically, articles 3 and 6(1) of the $\mathrm{CRC}$, and articles 4(1) and 5(1) of the ACRWC. The Court accordingly found the applicants liable for the damage suffered by the respondent. It then reaffirmed the judgment of the FFIC and ordered the applicants to pay the respondent the amount of Birr 31,300.

Apart from the Court's engagement with treaty and Bill of Rights provisions to determine the child's right to life, what is interesting about this case is the Court's recognition of the horizontal application of the child' right to life on non-state actors (NSA). The horizontal application of human rights to NSA is an evolving and contested legal area both comparatively and at the international level (Nolan 2014, $61,63)$. Despite this, the Court succeeded, interestingly, in addressing this lacuna by clearly determining the applicants to be responsible for violation of the right to life of a deceased child.

\section{Derivations from EFCC engagement of children's matters}

The recent literature amongst Ethiopian academics and others has overwhelmingly focused on the Ethiopian courts' deferential (or as some academics put it 'courts that prefer silencing') position, which largely fails to apply the provisions of the FDRE 
Constitution which includes the constitutionally consecrated substantive and procedural human rights guarantees. ${ }^{50}$ For instance, Bulto underscores that the courts have been considered to have retreated and surrendered their own territory (Bulto 2011: 123). These studies show that Ethiopian courts, generally, avoid constitutional issues and are reluctant to interpret or apply the provisions of the Constitution to the actual cases before them.

Two main reasons are attributed to the accusation that Ethiopian courts refer constitutional issues to the Council of Constitutional Inquiry (CCl) or the House of Federation (HoF). The first emanates from a position taken within judicial circles and beyond from the reading of the provisions of article 83(1) of the Constitution, which requires that 'all constitutional disputes' shall be decided by the HoF. Yeshanew (2008A: 143) argues that this provision suggests that courts are stripped of their mandate to interpret and apply constitutional provisions. It is taken for granted that the Constitution is not within the reach of the courts, and that judges would be exceeding their jurisdiction if they opted to directly interpret and apply the Constitution. Consequently, the regular courts have been 'loathe to do anything which might indicate that they are engaged in constitutional interpretation' (Mgbako et al 2008: 275). The second justification for such judicial deference relates to the court's inclination to avoid cases that are politically sensitive. However, this has repercussions, most importantly the fear of litigants of having their cases referred to the more political bodies (the $\mathrm{CCl} / \mathrm{HoF}$ ) which they seek to avoid in the same way that courts have avoided citing constitutional provisions (Yeshanew 2008b: 273). To justify this fear they even cite cases ${ }^{51}$ presented to court where an actual referral is made to the $\mathrm{CCl} / \mathrm{HoF}$. 
But, could this position be maintained on issues where children's rights are concerned? Despite the debate above, the decisions of the EFCC discussed in II.3.A. clearly indicate that Ethiopian regular courts have both the right and the duty to invoke human rights instruments in their judgments within the limits of their constitutional mandate. At the risk of oversimplification, the EFCC has, to a large extent, settled the debate that persists within academia as to whether Ethiopian courts should interpret and apply human rights provisions of the Ethiopian Constitution and the human rights instruments ratified by Ethiopia. Furthermore, although the number of cases so decided is not high, the jurisprudence is evolving and seemingly in a positive direction.

A pertinent inquiry to make is how the Court is able to achieve this positive development in the face of those critics? There could be various reasons that determine the Court's increasing reference to children's rights provisions. Due to space constraints it is not possible to chart all the factors that led to this progress, but, two causes deserve mentioning. Firstly, the growing attention being given to children's rights in the country is manifested in different ways. For instance, unlike other international conventions ratified by the country, the CRC was translated into five languages and disseminated throughout the country, and was also translated into Braille. ${ }^{52}$ This might have increased the judges' willingness to refer to the treaty. Similarly, although Ethiopia is known for delaying the submission of periodic reports to the various treaty bodies under several treaties, its record in connection with the submission of the periodic report to the CRC Committee is commendable. It recently submitted its fourth and fifth combined report to the same Committee and, at the time of writing, the report is pending issuance of the Committee's concluding observations and recommendations. On the basis of the Committee's recommendations issued in 
2006, training aimed at enhancing the capacity of the judiciary and other legal professionals on the application of CRC has been conducted, although there is still is a gap in capacity-building.$^{53}$ Secondly, the academic debate referred to above, such as the criticism raised against the judiciary for abdicating its constitutional mandate regarding interpretation and application of human rights provisions, may have influenced the Courts to assert their jurisdiction over children's rights in cases brought before them.

Consequently, following the incipient jurisprudence of the EFCC, more cases can now be brought before the lower courts deploying human rights instruments and children's human rights under the Bill of Rights provisions of the FDRE Constitution. The position of the Court in those cases conveys a message to lawyers, children or their legal representatives and children's rights advocates that cases regarding the violation of children's rights can be taken to court for remedial action. It further implies that children or their representatives can engage the CRC, ACRWC or the Bill of Rights of the FDRE Constitution to demand enforcement of the human rights of children. The nature of the cases that can be instituted before courts ranges from civil and political to economic, social, and cultural rights of children. This is precisely because, inter alia, the $\mathrm{CRC}$ and the ACRWC make no distinction on these traditional classifications of human rights, and these instruments underline the interdependence and indivisibility of all rights.

\section{Limitations of the EFCC}

Despite the progress achieved, only a limited number of children's matters received the Court's attention, despite the widespread violation of children's rights in the country. This shows the Court's limited role in promoting and protecting the human 
rights of children. Content wise, the Court's decisions lack deep analysis of the substantive meaning of the rights in question. For instance, the courts never mention how the content of the particular right and the obligation emanating there are articulated in the CRC Committee General Comments or other treaty bodies. ${ }^{54}$ Unlike courts in other countries such as South Africa, ${ }^{55}$ the full potential of the interpretive work of the UN bodies has not yet been realised by the Ethiopian highest judicial body in those cases under consideration. Although the General Comments are not strictly binding, they should be considered in defining the full scope and content of the rights in the treaties and Bill of Rights of the Constitution. Courts are institutions best situated to set out such definitions. Government would then have clear guidelines as to what is expected of it in the short, medium and long term. The executive arm of the government may not be aware of what the full scope and content of the rights are. Courts are better placed to analyse international law obligations and should provide guidance in terms of the full scope and content of the different rights to be incorporated into government plans. As noted by the Community Law Centre of South Africa in relation to Minister of Health \& others $v$ Treatment Action Campaign \& others, ${ }^{56}$ the full obligations of the state ought to be set out by the courts so that the state can plan and monitor accordingly. ${ }^{57}$

Similarly, the EFCC did not look at other countries' judgments with regard to children's rights issues. The heavily legalistic and formalistic approach of the Ethiopian judges in dealing with an exclusive analysis of human rights provisions is largely due to the influence of civil law in the country's legal system. In addition, the cases that the EFCC has adjudicated pertain to children's rights in relation to family matters. However, children's rights are not simply the right to be placed with a proper custodian. Most fundamentally, it includes specific rights laid down in those 
instruments discussed previously. For instance, children's right to education, health or food are equally important. Nolan (2007: 334) underlines that the socio-economic rights of children are vitally important from birth for their full physical and mental development and the long-term impact that any early deprivation of economic and social rights may have on their life chances as adults. Consequently, courts now play an increasing role in determining the rights of children to basic material entitlements to enable them live in dignity, both in low- and middle-income countries.

In contrast to the above, the EFCC, predominantly, has a tendency to use an 'open concept', the best interests principle, in dispensation of children's rights in the human rights instruments discussed. The jurisprudence of the Court is dominated by the application of article 3 of the CRC. Furhermore, the principle is applied to limited perspectives on children's rights. The same principle can be applied to the spectrum of children's rights discussed herein. For example, apart from family matters and children's criminal issues, the SACC has utilized the principle in relation to the right to basic education in the case of the Juma Musjid ${ }^{58}$ and a handful of others. Comparing the work of the SACC in the area of child rights jurisprudence, none of the cases decided by the EFCC has brought about similar far-reaching results to children living in extreme deprivation in terms of access to the basic right to education, or their other entitlements.

Liefaad and Doek (2015: 3) underscore that several challenges and limitations exist in litigating children's rights at the domestic level using global and regional children's rights instruments. The challenges and limitations include: (a) the nature of the (domestic) legal order; (b) the presence or absence of a domestic constitution in which children's rights have been embedded or on the basis of which international 
law is regarded as the higher law; (c) the legal tradition (civil law, common law or Islamic law); and (d) the existence or absence of strategic-litigation initiatives, including education and training of professionals. In the Ethiopian context, apart from the dilemma whether Ethiopian courts have the jurisdiction to interpret and apply human rights provisions highlighted in the preceding section, there are a host of legal and practical obstacles that are attributable to the EFCC's limited role in giving effect to other areas of children's rights or expansive use of the principle in the areas of children. The first is related to the status and domestication of the CRC and ACRWC in Ethiopia. Lundy et al (2012: 4) observe that in countries where the CRC has been fully incorporated into domestic law, it has had significant effect. Although, pursuant to article 9(4) of the FDRE Constitution that all international instruments ratified by Ethiopia are an integral part of the law of the land, the effort geared towards giving legal effect to human rights conventions on children appears to be inadequate (Alemu and Birmeta (2012: 45) Domestication of all international instruments to which Ethiopia is a party remains far from desired. It is for this reason that the CRC Committee is concerned that Ethiopia has not yet promulgated the CRC and ACRWC in its official law gazette, the Negarit Gazeta. ${ }^{59}$ As a result, the enforcement of these instruments has been partly affected by the failure to publish them in the official law gazette.

The second reason relates to representation. Judges cannot exercise their mandate without a case presented to them. Due to incapacity or their vulnerability, children require representation before judicial or non-judicial bodies. The role of civil society organisations (CSOs) cannot be underestimated. The selected children's right cases discussed in this article were backed by child rights representative groups. Such groups are relatively less evident in Ethiopia. None of the children's rights cases 
before the EFCC was litigated by child rights advocates or CSOs. Strict standing rules and the current Charities and Societies Proclamation (the CSO law) in Ethiopia is the huge limitation as it curtails the room for CSOs to get involved in children's human rights issues before courts or quasi-judicial bodies. ${ }^{60}$ The third limitation relates to the attitude of the judiciary and practitioners. The level of understanding of justiciability of children's rights is under developed within judicial circles. There is an indication that judges' understanding of human rights, more specifically socioeconomic rights, and their enforceability is at its lowest ebb (Bogale, 2010: 88; Tesfaye, 2010: 11; Tadesse, 2012: 300). This is partly because the content and meaning of human rights treaty provisions remains unknown to the courts and practitioners or they cannot easily trace the text of the treaty, especially in the language that the court works. (Assefa and Yohannes, 2006: 8). The matter becomes more complex due to the vague and inadequate formulation of economic, social and cultural rights under the FDRE Constitution (Yeshanew 2008b: 276) and absence of detailed and comprehensive separate legislation that specifically addresses children's issues. This is compounded by gaps in awareness of children's rights by stakeholders including law professionals. ${ }^{61}$ This is an indication that the country has a long distance to walk to meet its obligation of disseminating, training, and awareness-raising of these child rights implementing organs and persons, in accordance with the CRC Committee's General Comment $5 .^{62}$

\section{CONCLUSION AND THE WAY FORWARD}

In conclusion, judicial accountability mechanisms must be established when there is uncertainty among government and other actors regarding the implementation of children's rights and interests stipulated under human rights instruments and 
domestic laws. The experience of the SACC shows that the best interests principle can be deployed as one useful path to vindicate children's rights.

The EFCC's incipient judgments examined in this article demonstrate that global, regional, and domestic child rights instruments have played an important role in the emergence of child rights jurisprudence in Ethiopia. However, there is much more that can be done to promote the jurisprudence on children's rights, and to ultimately contribute to the actualization of the rights of those children living in extreme deprivation and poverty. It remains unanswered whether the EFCC can engage the executive branch of government to account for the failure to implement children's rights provided in the various instruments. There is a need for the judiciary and other law professionals to give equal weight to rights to all children. To facilitate this, the country must, in accordance with the CRC Committee General Comment 5, provide on-going training to these institutions and organs with the aim adequately to enforce all children's rights within their jurisdiction. Only then can the courts be considered an effective forum to vindicate the spectrum of children's rights. The mobilization of CSOs in children's human rights advocacy and litigation must also be promoted, as children have a more restricted ability to make rights claims than adults. However, the law relating to CSOs must be revised to enable the civil society work to continue unhampered. Similarly, there is a need to adopt more liberal procedural rules to make access to the courts easy for representatives of children's interest. ${ }^{63}$ The challenges of judicial application of children's rights are not insurmountable nor can they easily be solved overnight. Nevertheless, they demand swift action by all the agencies concerned and the time to start is now if the country takes the actualisation of children's rights seriously. 


\title{
ACKNOWLEDGMENTS
}

\author{
My thanks to Prof. A Skelton, Prof. D Brand, Lubaale, Chi Ngang and A.
}

Onuoraoguno, from University of Pretoria, South Africa, for their valuable comments

on earlier versions of this article. Errors are my own.

\section{NOTES}

1 The article does not discuss children's rights court cases decided in all these countries. However, for a more insightful engagement on children's rights and courts, see Nolan, A. (2010) 135-62. Again, for discussions on child rights court cases in Eastern and Southern Africa, see Skelton, A. (2009) 482500 . Also, for a recent review of the burgeoning social rights jurisprudence in 21 different national and international jurisdictions, see Langford. (2008: 75-590).

${ }^{2}$ United Nations General Assembly, Convention on the Rights of the Child (CRC), adopted and opened for signature, ratification and accession by General Assembly resolution 44/25 of 20 November 1989, entry into force on 2 September 1990. As of February 2015, the CRC has been ratified by 195 states including Somalia.

${ }^{3}$ African Charter on the Rights and Welfare of the Child (ACRWC), OAU Doc. CAB/LEG/24.9/49 (1990), adopted by the Heads of State and Government of the OAU on 11 July 1990, entry into force on 29 November 1999. As of October 2014, the ACRWC has been ratified by 47 of the 54 African Union states.

${ }^{4}$ Constitution of the Federal Democratic Republic of Ethiopia (FDRE Constitution), Proclamation 1/1995, entered into force and effect on 21 August 1995.

${ }^{5}$ I discuss the arguments set forward regarding the tendency of the EFCC in the application of human rights provisions more fully in section III of this article.

${ }^{6}$ These are rights which protect certain interests such as health, education, housing, food, and water. They entitle basic material things that people need to survive and live well. They have been included as enforceable constitutional rights in various jurisdictions such as, in most countries of South America, Eastern Europe and in South Africa. For a detailed discussion on socio-economic rights, see Brand (2005: 3); Brand. (2009) and Ferraz (2013: 375).

7 The League of Nations passed the Geneva Declaration on the Rights of the Child, http://www.refworld.org/docid/3ae6b38e3.html (accessed 1 April 2015) in September 1924. It was the earliest human rights instrument issued on the rights of the child. It emphasised the mandates of caring for and protecting children and focused on their basic material needs as well as essential conditions for normal development.

${ }^{8}$ Consider articles 4 \& 1(1) of the CRC \& ACRWC respectively, vis-à-vis article 2 of the International Covenant on Civil and Political Rights, and article 2 of the International Covenant on Economic, Social and Cultural Rights.

${ }^{9}$ In this category are children's rights to survival and development (article 5), health and health services (article 24), basic economic welfare (article 27), education (article 28) and play and recreation (article 31), provided under the CRC.

${ }^{10}$ Committee on the Rights of the Child, General Comment 14: The right of the child to have his or her best interests taken as a primary consideration (2013) para 6.

11 lbid, para 37.

12 The cases that Skelton has identified include: Minister of Welfare and Population Development $v$ Fitzpatrick \& others 20003 SA 422 (CC) para 20; Sonderup v Tondelli 2001 (1) SA 1171 (CC) paras 33 \& 35; De Reuck v Director of Public Prosecutions (Witwatersrand Local Division) 2004 (1) SA 406 (CC) paras 54-5; S v M (Centre for Child Law as Amicus Curiae) 20083 SA 232 (CC) paras 12-27. See Skelton (2009: 487).

${ }_{11}^{13}$ Committee on the Rights of the Child, General Comment 14, para 16(a).

14 lbid, para 29.

${ }^{15}$ For insightful discussion on these provisions, see Howe \& Covell. (2003: 1070). 
${ }^{16}$ Committee on the Rights of the Child, General Comment 12: The right of the child to heard (2009) para 3.

${ }^{17}$ Committee on the Rights of the Child, General Comment 5: General measures of implementation of the Convention on the Rights of the Child (2003) para 1.

${ }^{18}$ Not only through judicial means but also that children's rights can be directly claimed before treaty bodies or quasi-judicial mechanisms. Entered into force on 14 April 2014, the third Optional Protocol to the Convention on the Rights of the Child (OP3-CRC) allows children and their representatives from states that have ratified to bring complaints about violations of their rights, under the Convention on the Rights and the Child, as well as the Optional Protocols to that instrument on the Sale of Children and Children in Armed Conflict, directly to the UN Committee on the Rights of the Child if they have not found a solution at national level.

${ }^{19}$ M v The State (Centre for Child Law as Amicus Curiae), Case CCT 53/06 [2007] ZACC 18; [2000] 10 BCLR 1051 (CC); [2000] 7 BCLR 713 (CC), para 12.

${ }^{20}$ In addition to the cases discussed in this article, other cases where the SCC made reference to the best interests principle include, $M v$ The State (ibid), dealing with whether the best interests of the child would be served if the primarily caregiver were jailed; [2000] 10 BCLR 1051 (CC), relating to the constitutionality of government's ban on corporal punishment in non-government religious schools; [2000] 7 BCLR 713 (CC), relating to the constitutionality of a provision which prohibits adoption of South African children by people who are not citizens of this country; Bhe \& others $v$ Magistrate, Khayalitsha \& others (Commission for Gender Equality as Amicus Curiae) (CCT 49/03) [2004] ZACC 17; 2005 (1) SA 580 (CC); 2005 (1) BCLR 1 (CC) (15 October 2004), relating to whether the best interests principle should be considered on the issue of custody (this consideration appears to be in conflict with customary law); Van der Burg \& another $v$ National Director of Public Prosecutions (Centre for Child Law as Amicus Curiae) 2012 (2) SACR 331 (CC), where the best interests is applied in asset forfeiture cases.

${ }^{21}$ The cases that Skelton (2014: 18-19) has identified in this regard include, Government of the Republic of South Africa v Grootboom 2001 (1) SA 46 (CC); Bannantyne v Bannantyne (2003) (2) SA 363 (CC); Du Toit v Ministry of Welfare and Urban Development (Lesbian and Gay Equality Project as Amicus Curiae) (2003) (2) SA 198(CC); C \& others v Department of Social and Health Development \& others 2012 (2) SA 208 (CC); Sonderup v Tondelli 2001 (1) SA 1171 (CC); De Reuck v Director of Public Prosecutions (Witwatersrand Local Division) 2004 (1) SA 406 (CC); Ministry of Health $v$ Treatment Action Campaign 2002 (5) SA 721 (CC); Governing Body of the Juma Musjid Primary School v Essay NO (Centre for Child Law as Amicus Curiae) 2011 (8) BCLR 761 (CC); Khosa v Ministry of Social Development; Mahaule v Ministry of Social Development 2004 (1) SA 505 (CC); Fraser v Children's Court (Pretoria North) 1997 (2) SA 261 (CC)..

${ }^{22}$ In recognition of their vulnerability, article 36 of the FDRE Constitution provides additional protection through constitutional provisions which include the right to life; name and nationality; not to be subject to exploitative practices; not to be required nor permitted to perform work which may be hazardous or harmful to his or her education, health or wellbeing; to be free of corporal punishment or cruel and inhumane treatment in schools and other institutions responsible for the care of children; to be kept separately from adults in justice on wards of a state. It also provides further protection to children by indicating the best interests of the child as the primary consideration in all actions concerning them. However, this article fails to incorporate explicitly children's socio-economic rights unlike, for instance, section 28 of the South African Constitution. However, as socio-economic rights are justiciable under the FDRE Constitution they equally apply to children, despite the fact that article 36 of the FDRE Constitution lacks clarity in this category of children's rights. In addition, children's socio-economic rights stipulated under the CRC \& ACRWC have the force of law before courts by way of articles 9(4) and 13(2) of the FDRE Constitution.

${ }^{23}$ Ethiopia acceded to it on the 14 May 1991. This is the time where the current movement (EPDRF) took control over almost all part of the country against the then Derg government which was toppled militarily on the same month.

${ }^{24}$ Ethiopia ratified the African Charter on the Rights and Welfare of the Child in 2002.

${ }^{25}$ For instance, Ethiopia still does not come up with a comprehensive children's rights act, despite a long awaited demand for it.

${ }^{26}$ UN Committee on Economic Social and Cultural Rights: Concluding Observations of the Committee on Economic, Social and Cultural Rights (Ethiopia) (2012) para 4, http://www.refworld.org/docid/4aa7aa642.html (accessed 4 November 2014).

${ }^{27}$ Central Statistical Agency (Ethiopia) \& ICF International (2012) 111. 
${ }^{28}$ UN Committee on the Rights of the Child: Concluding Observations (Ethiopia) (1 November 2006) $\mathrm{CRC} / \mathrm{C} / \mathrm{ETH} / \mathrm{CO} / 3$ para 63, http://www.refworld.org/docid/45c30bd60.html (accessed 4 April 2015).

${ }^{29}$ lbid.

${ }^{30}$ UN Committee on the Rights of the Child (CRC), General Comment 16 (2013) on State obligations regarding the impact of the business sector on children's rights, 17 April 2013, CRC/C/GC/16 para 4, http://www.refworld.org/docid/51ef9cd24.htm (accessed 46 April 2015).

${ }^{31}$ Federal Courts Proclamation Re-amendment, Proclamation 454/2005, article 2(4)).

${ }^{32}$ (Federal Supreme Court Cassation Division) Cass File 23632, judgment 6 November 2007.

${ }^{33}$ Currently, Ethiopia is a federal state with nine regions/states and two administrative cities. SNNPRS is one such unit. Article 52(1) of the FDRE Constitution allows states for administrative convenience to issue proclamations on matters falling under their jurisdiction. On the basis of this article, for instance, the states of Amhara, Oromia, the Southern Nations, Nationalities and People, and Tigray have enacted their own Family Codes. A more comprehensive description of the Ethiopian legal system can be found in Alemu, G. (2010); and Wondirad, A. (2013) 93-117.

${ }^{34}$ Family Code of the Southern, Nations, Nationalities and Peoples Regional State, Proclamation $75 / 2004$.

${ }^{35}$ The Civil Procedure Code of the Empire of Ethiopia, Decree 52 of 1965.

${ }_{37}^{36}$ (Federal Supreme Court Cassation Division) Cass File 23632, judgment 6 November 2007.

${ }^{37}$ The Constitution employs the phrase 'the primary consideration'. In this sense it exhibits a similar wording with the ACRWC than the CRC.

${ }_{38}^{38}$ (Federal Supreme Court Cassation Division) Cass File 35710, 25 December 2009.

39 (Federal Supreme Court Cassation Division) Cass File 44101, 3 March 2010.

40 lbid.

${ }^{41}$ (Federal Supreme Court Cassation Division) Cass File 25691, 30 April 2010.

${ }^{42}$ For a greater engagement concerning the emerging trends on children's right to be heard within the European Court of Human Rights, see Daly (2011: 441)..

${ }_{43}$ (Federal Supreme Court Cassation Division) Cass File 35710, 25 December 2009.

${ }^{44}$ Such as the Universal Declaration on Human Rights (UDHR) (1948) article 3; the International Covenant on Civil and Political Rights (ICCPR) (1966) article 6; CRC, article 6(1).

${ }^{45}$ See, for instance, the African Charter on Human and Peoples' Rights (1981) article 4; European Convention for the Protection of Human Rights and Fundamental Freedoms (1950) article 2; American Convention on Human Rights (1969) article 4; Arab Charter on Human Rights (2004) articles 5-7; ACRWC article 5(1).

${ }^{46}$ To locate examples see, Constitution of the Republic of South Africa (1966) section 11; Constitution of the Republic of India (1949) article 21; Constitution of Colombia (1999) chapter 1, article 11.

${ }^{47}$ (Federal Supreme Court Cassation Division) Cass File 92020, 24 December 2014.

${ }^{48}$ This Code defines the procedure for all types of civil cases in court unless otherwise provided by the specific legislation providing for a particular right.

${ }^{49}$ The Civil Procedure Code of the Empire of Ethiopia, Decree 52 of 1965.

${ }^{50}$ Bulto (2011). For a comprehensive engagement on the position of the Ethiopian Court on the application of human rights provisions see, Mgbako et al (2008: 259, 275); Yeshanew (2008a: 135, 144); Fessha (2006: 53, 79).

${ }^{51}$ The most important case cited in this regard is Coalition for Unity and Democracy $v$ the late Prime Minister Meles Zenaw Asres (Federal First Instance Court) File No 54024, 3 June 2005.

52 'Committee on the Rights of the Child examines the report of Ethiopia' http://www.ohchr.org/EN/NewsEvents/Pages/DisplayNews.aspx?NewsID=16002\&LangID=E\#sthash. 3Xrdp9jW.dpuf (accessed 10 November 2015).

${ }^{53}$ Committee on CRC 'Consideration of reports submitted by States Parties under article 44 of the Convention Fourth and fifth periodic reports of States Parties due in 2011: Ethiopia' paras 58-64, < file:///C:/Users/u11190184/Desktop/G1349926.pdf (accessed 20 October 2015).

${ }^{54}$ There are currently ten treaty bodies under the UN human rights system. These bodies and their specific roles can be found at International Justice Resource, UN Human Rights Treaty Bodies, http://www.ijrcenter.org/un-treaty-bodies/ (accessed 12 February 2015).

${ }^{55}$ The South African Constitutional Court has utilised General Comments issued by UN bodies. See for instance, Government of the Republic of South Africa v Grootboom 2001 (1) SA 46 (CC) para 31.

${ }^{56}$ Ministry of Health v Treatment Action Campaign 2002 (5) SA 721 (CC). 
${ }^{57}$ Community Law Centre In re Certain Amicus Curiae Applications relating to Minister of Health \& others $v$ Treatment Action Campaign \& others 19,

http://www.communitylawcentre.org.za/ser/docs_2002/TAC_MTCT_Case_Heads_of_Arguments.doc (accessed 22 February 2015).

${ }^{58}$ Governing Body of the Juma Musjid Primary School v Essay NO (Centre for Child Law as Amicus Curiae) 2011 (8) BCLR 761 (CC).

${ }^{59}$ Committee on CRC 'Consideration of reports submitted by States Parties under article 44 of the Convention Fourth and fifth periodic reports of States Parties due in 2011: Ethiopia', 23 December 2013, CRC/C/ETH/4-5, para 9, http://www.refworld.org/docid/555dc2e64.html (accessed 20 November 2015).

${ }^{60}$ The Charities and Societies Proclamation 621/2009 of Ethiopia (often referred as CSO law) imposes limitations on the activities of all CSOs that do not fit the CSO law's definition of 'Ethiopian' Charities/Societies. Per this law, 'Ethiopian' Charities/Societies (NGOs) are prohibited to participate, including but not limited to, in the advancement of human and democratic rights (article 14(2)(j)); and the promotion of the rights of the disabled and children's rights (article 14(2)(I)). For a comprehensive engagement on this law, see Center for International Human Rights North-Western University School of Law (2009); and Kassie (2012)

${ }^{61}$ Awareness of children's rights is crucial for their overall implementation. However, knowledge about the rights of children has been considered as a main challenge in the country. Concerning this, consider UN Committee on the Rights of the Child, Concluding Observations of the Committee on the Rights of the Child: Ethiopia, 1 November 2006, $\mathrm{CRC} / \mathrm{C} / \mathrm{ETH} / \mathrm{CO} /$ para 20, <http://www.unhcr.org/refworld/docid/45c30bd60.html (accessed 10 February 2015).

${ }^{62}$ Paras $1 \& 53-55$.

${ }^{63}$ There are relatively strict standing rules in the various existing laws of Ethiopia. For a comprehensive account regarding standing rules in Ethiopia see, Kassie (2010); Yeshanew (2008b: 290-2) and Badwaza (2005: 40).

\section{REFERENCES}

Alemu, G. (2010) Introduction to the Ethiopian Legal System and Legal Research. Addis Ababa: Addis Ababa University: http://www.nyulawglobal.org/globalex/Ethiopia.html (accessed 25 February 2015).

Alemu, G. \& Birmeta, Y. (2012) Handbook on the Rights of the Child in Ethiopia. Addis Ababa: Addis Ababa University, 45-105.

Alston, P \& Tobin, J (2005) Laying the Foundations for Children's Rights. Florence: United Nations Children's Fund (UNICEF), 7-8.

Assefa, A. \& Yohannes, S. (2006) Harmonisation of National and International Laws to Protect Children's Rights: The Ethiopia Case Study. Addis Ababa: (Unpublished Report, Africa Child Policy Forum), 8-17.

Badwaza, Y.M. (2005) 'Public interest litigation as practised by South African NGOs: any lessons for Ethiopia?' unpublished LLM thesis, University of Pretoria, 40.

Bogale, S. (2010) 'Competence and legitimacy of Ethiopian courts in the adjudication of socioeconomic rights: an appraisal of the challenges and prospects' unpublished LLM thesis, Addis Ababa University, 88.

Bonthuys, E. (2006) 'The best interests of children in the South African Constitution' International Journal of Law, Policy and the Family 20, 23-43.

Brand, D. (2005) 'Introduction to socio-economic rights in the South African Constitution' in D. Brand \& C.H. Heyns (eds) Socio-Economic Rights in South Africa. Pretoria: Pretoria University Law Press, 3-56.

Brand, D. (2009) 'Courts, socio-economic rights and transformative politics' (2009) unpublished LLD dissertation, University of Stellenbosch. 
Bulto, T. (2011) 'Judicial referral of constitutional disputes in Ethiopia: from practice to theory' African Journal of International and Comparative Law 19, 99-123.

Cantwell, N. (2011) 'Are children's rights still human?' in A. Invernizzi \& J. Williams (eds) The Human Rights of Children: From Visions to Implementation. Surrey: Ashgate Publishing Limited, 37-59.

Center for International Human Rights, North-Western University School of Law (2009) 'Sounding the horn: Ethiopia's civil society law threatens human rights defenders', http://www.law.northwestern.edu/legalclinic/humanrights/documents/EthiopiaCSOPaper-Nov2009.pdf (accessed 13 January 2015).

Central Statistical Agency (Ethiopia) \& ICF International (2012) Ethiopia Demographic and Health Survey 2011. Addis Ababa, Ethiopia and Calverton, Maryland, USA: Central Statistical Agency and ICF International, 110-117.

Covell, K. \& Howe, R. (2001) The Challenge of Children's Rights for Canada. Waterloo: Wilfrid Laurier University Press, 23-36.

Daly, A. (2011) 'The right of children to be heard in civil proceedings and the emerging law of the European Court of Human Rights' The International Journal of Human Rights 15:3, 441-461.

Ferraz, O. (2013) 'Between usurpation and abdication? The right to health in the courts of Brazil and South Africa' in O Vilhena et al (eds) Transformative Constitutionalism: Comparing the Apex Courts of Brazil, India and South Africa. Pretoria: Pretoria University Law Press, 375-404.

Fessha, Y. (2006) 'Judicial review and democracy: a normative discourse on the (novel) Ethiopian approach to constitutional review' African Journal of International and Comparative Law 14, 53, 79.

Gebrekristos, K. et al (2014) 'A cross sectional study on factors associated with harmful traditional practices among children less than 5 years in Axum town, north Ethiopia, 2013' Reproductive Health $11: 46,1-7$.

Goel, V. (2009) 'Children's human rights in underdeveloped country: a study in Ethiopian perspective' African Journal of Political Science and International Relations 3,152-155.

Guari, V. \& Brinks, D. (eds) (2008) Courting Social Justice: Judicial Enforcement of Social and Economic Rights in the Developing World. New York: Cambridge University Press, 1-37.

Hodgkin, R. \& Newell, P. (2007) 'The child's right to life and maximum survival and development' in R. Hodgkin et al (eds) An Implementation Handbook on the United Nations Convention on the Rights of the Child. New York: UNICEF, 83-96.

Howe, R. \& Covell, K. (2003) 'Child poverty in Canada and the rights of the child' Human Rights Quarterly 25, 1070-1087.

Humanium (2012) 'Children of Ethiopia: realising children's rights in Ethiopia', http://www.humanium.org/en/ethiopia/ (accessed 23 February 2015).

Humanium (n.d.) 'Right to life: understanding children's right to life', http://www.humanium.org/en/fundamental rights/life/ (accessed 24 January 2015).

Kassie, A. (2010) 'Towards more liberal standing rules to enforce constitutional rights in Ethiopia' African Human Rights Law Journal 10, 408-31.

Kassie, A. (2012) 'The potential role of constitutional review for the realization of human rights in Ethiopia' unpublished LLD dissertation, University of Pretoria, 186-216. 
Langford, M. (ed) (2008) Social Rights Jurisprudence: Emerging Trends in International and Comparative Law. Cambridge: Cambridge University Press, 75-590.

Liebenberg, S. (2010) Socio-Economic Rights: Adjudication under a Transformative Constitution. Claremont: Juta \& Co Ltd, 23-78.

Liefaard, T. \& Doek, J.E. (2014) 'South Africa' in Liefaard, T. \& Doek, J.E. (eds) Litigating Children's Rights: The UN Convention on the Rights of the Child in Domestic and International Jurisprudence. The Netherlands: Springer, 3-11.

Lundy, L. et al (2012) The UN Convention on the Rights of the Child: A Study of Legal Implementation in 12 Countries. UNICEF: United Kingdom, 3-8.

Mgbako, C. et al (2008) 'Silencing the Ethiopian courts: non-judicial constitutional review and its impact on human rights' Fordham International Law Journal 32, 259, 275.

Nolan, A. (2007) 'A role for the courts in ensuring the enforcement of the socio-economic rights of the child: overcoming the "counter-majoritarian objection"' in A. Alen et al (eds) The UN Children's Rights Convention: Theory meets Practice. The Netherlands: Intersentia, 333-358.

Nolan, A. (2010) 'The child's right to health and the courts' in J. Harrington \& M. Stuttaford (eds) Global Health and Human Rights: Legal and Philosophical Perspectives. London: Routledge, 135-62.

Nolan, A. (2014) 'Holding non-state actors to account for constitutional economic and social rights violations: Experiences and lessons from South Africa and Ireland' (2014) International Journal of constitutional Law 12, 65-93.

Olowu, D. (2002) 'Protecting children's rights in Africa: a critique of the African Charter on the Rights and Welfare of the Child' The International Journal of Children's Rights 10, 127-135.

Rosa, S. \& Dutschke, M. (2006) Child Rights at the Core: A Commentary on the Use of International Law in South African Court Cases on Children's Socio-Economic Rights. Cape Town: Children's Institute of University of Cape Town, 6-15.

Save the Children Sweden (2010) A Study on Child Protection Mechanisms in Ethiopia. Addis Ababa: Save the Children Sweden, 1-34.

Skelton, A. (2003) 'The role of the courts in ensuring the right to a basic education in a democratic South Africa: a critical evaluation of recent education case law' De Jure 6.

Skelton, A. (2009) 'The development of a fledgling child rights jurisprudence in Eastern and Southern Africa based on international and regional instruments' African Human Rights Law Journal 9, 482500 .

Skelton, A. (2014) 'South Africa' in Liefaard, T. \& Doek, J.E (eds) Litigating Children's Rights: The UN Convention on the Rights of the Child in Domestic and International Jurisprudence. The Netherlands: Springer, 18-19.

Tadesse, M. (2012) 'A rights-based approach to HIV prevention, care, support and treatment: a review of its implementation in Ethiopia' unpublished PhD dissertation, University of Alabama, 300.

Tesfaye, A. (2010) 'Justifiability of socio-economic rights in the Federal Democratic Republic of Ethiopia' unpublished LLM thesis, Addis Ababa University, 11.

Van Bueren, G. (1999) 'Alleviating poverty through the Constitutional Court' South African Journal of Human Rights 15, 55-73. 
Viljoen, F. (2000) 'The African Charter on the rights and welfare of the child' in C.J. Davel (ed) Introduction to Child Law in South Africa 214-218.

Viljoen, F. (2009) 'Recent publication’ African Human Rights Law Journal 9, 353-355.

Wondirad, A. (2013) 'An overview of the Ethiopian legal system' NZACL YEARBOOK 19, 93-117.

Yeshanew, S. (2008a) 'The constitutional protection of economic and social rights in the Federal Democratic Republic of Ethiopia' Journal of Ethiopian Law 23, 135, 144.

Yeshanew, S. (2008b) 'The justiciability of human rights in the Federal Democratic Republic of Ethiopia' African Human Rights Law Journal 8, 273-293. 